\title{
Aplikasi Model Epidemologi dalam Penentuan Premi Asuransi Penyakit Infeksi Emerging
}

\author{
Sri Dewi Anugrawati \\ Program Studi Matematika, Universitas Islam Negeri Alauddin Makassar, sridewi.anugrawati@uin-alauddin.ac.id \\ Rahma Sri Susanti \\ Program Studi Kesehatan Masyarakat, Universitas Indonesia Timur, rahmasrisusanti86@gmail.com
}

\begin{abstract}
ABSTRAK, Berbagai kasus penyakit infeksi emerging yang terjadi mengakibatkan kerugian yang besar tidak hanya kerugian ekonomi namun korban jiwa yang cukup banyak. Jumlah kematian yang semakin meningkat dikarenakan penyakit baru yang timbul mendorong para ahli untuk mencari cara pencegahan dan penanganannya. Hal ini tentu saja berpengaruh ke bidang asuransi kesehatan yang pasti akan terdampak pada meningkatnya klaim perawatan kesehatan bahkan kematian. Oleh karnea itu sangat penting untuk memtimbangkan berbagai aspek dalam perhitungan premi wajar pada asuransi kesehatan. Pada penelitian ini premi ditentukan beradasrakan modle kompartemen SIR dengan fomus utama padan pennetuan tingakt transmisi (tingkat penularan) dengan menggap tingkat kematian dan kesembuhan konstan. Berdasarkan data kasus baru penderita Covid-19 di Indonesia pada kuartal kedua tahun 2020, diperoleh tingkat premi semakin meningkat seiring meningkatnya jumlah santunan kematain dan biaya perawatan pasien yang ditamwarkan priduk asuransi infeksi emerging
\end{abstract}

Kata Kunci: Model epidemologi SIR, penyakit menular, Penyakit Infeksi Emerging, tingkat premi, pemodelan penyakit

\section{PENDAHULUAN}

Kesehatan adalah hak setiap orang di dunia ini. Hak seseorang untuk hidup sehat dan mendapatkan pelayanan kesehatan di Indonesia telah diatur dalam UUD 1945 Pasal 28 Ayat 1. Oleh karena itu negara wajib menjamin setiap warga untuk dapat hidup sehat, terbebas dari berbagai jenis penyakit.

Permasalahan kesehatan di Indonesia masih menjadi salah satu fokus utama pemerintah khususnya sejak awal tahun 2020 dikarenakan adanya wabah virus Corona yang mengakibatkan timbulnya wabah penyakit menular Covid-19 di seluruh dunia tak terkecuali di Indonesia.

Penyakit menular merupakan salah satu jenis penyakit yang masih jarang mendapatkan perhatian dari para pelaku asuransi kesehatan. Hal ini dikarenakan sifat penularan dari penyakit ini yang menjadikan penderita penyakit menular bisa bertambah dengan cepat dalam jangka waktu yang singkat. Oleh karena itu biasanya asuransi untuk berbagai jenis penyakit menular tidak digabungkan dengan proteksi kesehatan berupa asuransi kesehatan umum.

Proteksi untuk asuransi penyakit menular bisa bermacam-macam dimulai dari saat terinfeksi sehingga butuh perawatan rumah sakit sampai sembuh hingga santunan jika terjadi kematian. Hal ini harus menjadi pertimbangan dalam penentuan nilai premi asuransi. Oleh karena itu dalam artikel ini digunakan model epidemologi yang akan menggambarkan proses infeksi dari suatu penyakit hingga pasien sembuh total atau bahkan meninggal. Model epidemologi membantu para aktuaris agar dapat menentukan jumlah santunan untuk perawatan dan santunan kematian jika pasien sampai di state tertentu.

Beberapa penelitian sebelumnya terkait dengan aplikasi model epidemologi dalam matematika aktuaria, diantaranya: Penelitian oleh Feng dan Garrido [3][4] mengenai metodologi aktuaria untuk penentuan premi dan cadangan asuransi berdasarkan model kompartemen SIR, penelitian oleh Lefèvre, Picard, dan Simon [8] yang menggunakan model perluasan SIR untuk menentukan komponen biaya dan premi dari suatu desain asuransi risiko epidemi pada suatu populasi serta penelitian oleh Hainaut [7] terkait desain valuasi aktuaria asuransi kesehatan beserta santunan kematian dengan menggunakan model risiko pandemik deterministik dan stokastik yang merupakan alternatif dari model SIR. 


\section{KAJIAN TEORI}

\section{Penyakit Infeksi Emerging}

Penyakit infeksi emerging (emerging infectious disease) yang disingkat EIDs adalah salah satu dari penyakit infeksi menular yang sangat diwaspadai. Kemunculan penyakit ini dalam beberapa tahun terakhir mengakibatkan korban jiwa yang begitu besar serta kerugian sosial ekonomi di setiap negara atau wilayah yang terjangkit [12][13]

Menurut Word Health Organization (WHO), penyakit infeksi emerging adalah penyakit yang yang telah terjadi pada manusia dan menular dengan sangat cepat atau bahkan menjadi ancaman di masa depan, termasuk juga penyakit yang menyebar dengan sangat cepat di suatu daerah yang baru atau muncul kembali setelah lama tidak ada kasus[12]. Beberapa dari penyakit ini yang cukup memakan korban jiwa adalah: Flu Burung, Chikungunya, Demam Berdarah, Penyakit virus Ebola, Hantavirus, Virus Nipah, Novel coronavirus pada manusia dan Hepatitis[13]. Adapun penyakit Covid-19 yang disebabkan oleh Virus SARS-CoV-2 oleh Heider [6] digolongkan sebagai penyakit infeksi emerging yang kemungkinan berasal dari hewan Berdasarkan Peraturan Menteri Kesehatan Republik Indonesia Nomor 59 Tahun 2016 Tentang Pembebasan Biaya Pasien Penyakit Infeksi Emerging Tertentu, jenis-jenis penyakit infeksi emerging adalah : Penyakit infeksi emerging tertentu meliputi: poliomielitis, penyakit virus ebola, penyakit virus MERS, influensa A (H5N1)/Flu burung, penyakit virus hanta, penyakit virus nipah, demam kuning, demam lassa, demam congo, meningitis meningokokus, dan penyakit infeksi emerging baru [14].

Penyakit-penyakit infeksi emerging ini membawa kerugian yang besar bagi umat manusia contohnya saja virus flu burung. Dari tahun 2003 hingga 2013, dikonfirmasi kasus pada manusia varian $\mathrm{A}(\mathrm{H} 5 \mathrm{~N} 1)$ yang dilaporkan ke WHO dari 15 negara, 385 meninggal. Dari jumlah tersebut, 228 kasus $(35 \%)$ dan 181 kematian (47\%) berasal dari Asia Tenggara termasuk Indonesia yang juga memiliki jumlah kasus flu burung tertinggi di dunia[11]. Sama halnya dengan virus SARS-CoV-2 yang menyebabkan penyakit Covid-19, dimana telah ada 245 juta orang yang terjangkit dan 4,96 juta jiwa meninggal. Dampak ekonomi yang ditimbulkan juga sangat besar seperti di Indonesia yang mengalami kerugian mencapai 1.356 triliun di tahun 2020 akibat pandemi Covid-19 [15].

\section{Model Matematika Penyakit Menular}

Pemodelan matematika pada penyakit menular bertujuan untuk mendeskripsikan proses transmisi dari penyakit tersebut dimana ketika seorang individu masuk ke dalam populasi suspek penyakit infeksi penyakit menular, maka penyakit tersebut bisa saja menular ke individu itu melalui suatu proses transmisi dan menyebar ke dalam seluruh anggota populasi. Hal ini disebabkan karena adanya host (manusia) yang menjadi perantara virus/bakteri untuk menular dari seorang individu ke individu lainnya. Proses pemodelan matematika pada kasus penyakit infeksi menular terdiri atas enam tahapan yaitu [9]:

1. Penentuan asumsi terkait proses transmisi

2. Membentuk model matematika dari proses transmisi berdasarkan asumsi yang telah ditentukan

3. Analisis model matematika yang telah dibentuk

4. Interpretasi model

5. Validasi model menggunakan data

6. Perbaikan model dengan memodifikasi asumsi-asumsi sebelumnya

Beberapa model matematika merupakan model yang terbentuk dari suatu proses transmisi penyakit yang sering disebut juga model epidemologi penyakit. Model awal yang paling sering digunakan adalah model kompartemen oleh Kermack dan McKendrick yang disebut model SIR. Model ini membagi populasi ke dalam beberapa kelompok yaitu kelompok penjamu (host) sebagai $S$ yaitu kelompok rentan (suspectible), $I$ sebagai kelompok terinfeksi penyakit (infected), dan $R$ sebagai kelompok yang sembuh dari infeksi penyakit (Recovery)[2][9]. Model ini digambarkan dalam beberapa kompartemen seperti pada gambar berikut 


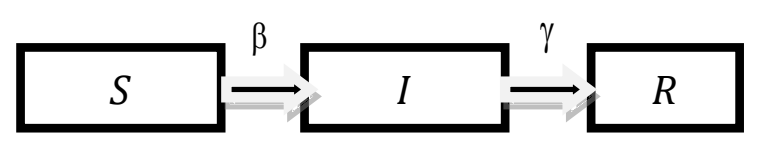

Gambar 2.1 Model SIR

Sumber: (Li, 2018)

Model diatas dapat dituliskan dalam suatu persamaan diferensial sebagai berikut

$$
\begin{aligned}
& \frac{d S}{d t}=-\beta I S \\
& \frac{d I}{d t}=\beta I S-\gamma I \\
& \frac{d R}{d t}=\gamma I
\end{aligned}
$$

Dengan kondisi awal $S(0)=S_{0}>0$, $I(0)=I_{0}>0$, dan $R(0)=R_{0} \geq 0$ [9]

Model SIR didasarkan pada beberapa asumsi [3]:

1. Jumlah individu dianggap konstan yaitu $S_{0}=N=S(0)+I(0)+R(0)$

2. Kontak masing-masing individu cukup untuk menularkan penyakit dengan kata lain $\beta$ konstan

3. $\gamma$ dinggap konstan. Jika terdapat individu yang sembuh dari penyakit, maka akan terdapat nilai $\gamma$

4. Tidak ada individu baru yang amsuk ke dalam populasi. Hanya ada kematian yang mungkin terjadi dikarenakan penyakit
Model lainnya yang merupakan pengembangan dari dari model SIR ini diantaranya adalah model SIRS dimana pada model ini orang yang telah sembuh (recover) dapat kembali menjadi suspek penyakit, model SEIR dengan penambahan kemungkin pra infeksi sebelum kejadian terinfeksi penyakit, dan SEIRS dimana pada model SEIR ada kemungkinan untuk kembali kedalam kelompok yang rentan atau suspek terhadap penyakit tertentu.

Model lainnya yang sering digunakan adalah model SI yaitu model yang tidak memberikan peluang sembuh dan SIS dimana pada model ini pasien yang terjangkit penyakit infeksi akan kembali rentan untuk terjangkit lagi. Kedua model ini secara berurutan sering digunakan untuk menggambarkan model penyakit HIV-AIDS dan penyakit menular seksual seperti gonore[16]

Jika diasumsikan individu yang ada di dalam populasi pada waktu ke-t, pada tingkat $b(t)$, tingkat kematian (mortality rate) sebesar $\mu(t)$, dan tingkat kesembuhan dari penyakit infeksi sebesar $\alpha(t)$ maka dapat digambarkan model SIR dengan skema seperti gambar 2.2

Menurut (Mubayi et al., 2021), skema diatas dapat dimodelkan ke dalam suatu persamaan diferensial seperti pada persamaan (2.1), (2.2), dan (2.3) yaitu

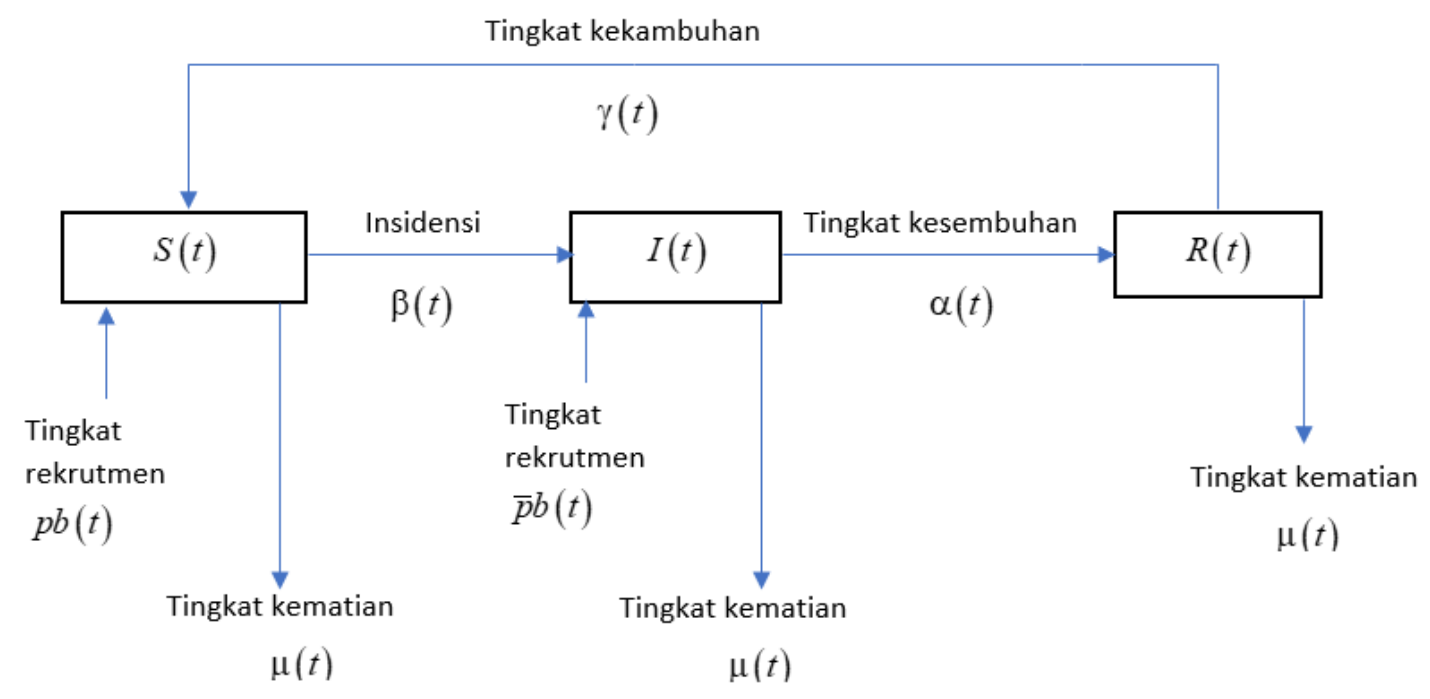

Gambar 2.2 Diagram Skematik untuk Model SIR

Sumber (Mubayi et al., 2021), 


$$
\begin{aligned}
& \frac{d S(t)}{d t}=p b(t)-\beta(t) S I+\gamma(t) R-\mu(t) S \\
& \frac{d I}{d t}=\bar{p} b(t)-\beta(t) S I-\alpha(t) I-\mu(t) I
\end{aligned}
$$

dengan

$$
R(t)=1-S(t)-I(t) .
$$

Untuk

menentukan nilai $\beta(t)$ sebagai fungsi dari insidensi $w(t)=\beta(t) S I$ maka terlebih dahulu ditentukan solusi untuk $I$ dengan kondisi awal $I(t)$ yaitu

$$
\begin{gathered}
I(t)=I(t) H(T, t)-\int_{t}^{T} H(s, t) \\
\\
{[w(s)+\bar{p} b(s)] d s}
\end{gathered}
$$

dengan

$$
H(T, t)=\exp \left(-\int_{t}^{T}(\alpha(s)+\mu(s)) d s\right)
$$

Selanjutnya persamaan (2.6) kita subtitusikan ke dalam persamaan (2.4) dengan nilai awal $S(0)$ sehingga diperoleh

$$
\begin{aligned}
S(t)= & Z(0, t) S(0)+\int_{0}^{t} Z(s, t) \\
& {[p b(s)-w(s)] d s } \\
& +\int_{0}^{t} Z(s, t) \gamma(s) \\
& {[1-I(T) H(T, s)} \\
& +\int_{s}^{T} H(u, s)[w(u)+\bar{p} b(u)] \\
& d u] d s
\end{aligned}
$$

Maka diperoleh

$$
\beta(t)=\frac{w(t)}{S I}
$$

Oleh karena itu untuk mengestimasi tingkat transmisi $\beta(t)$ digunakan formula yang dikemukakan oleh (Mubayi et al., 2021) sebagai berikut

$$
\begin{aligned}
\hat{\beta}(t)= & \frac{w(t)}{\left(S(0)-\int_{0}^{t} w(u) d u\right)} \\
& \times \frac{1}{\left(I(T) e^{\alpha(T-t)}-\int_{0}^{T} e^{\alpha(T-t)} w(s) d s\right)}
\end{aligned}
$$

Dimana jika persamaan diatas didiskritisasi maka diperoleh

$$
\hat{\beta}(t) \approx \frac{w(t)}{x y}, t \leq T
$$

dengan

$$
x=S(0)-h\left[\frac{w(0)+w(t)}{2}+\sum_{k=1}^{n-1} w(k h)\right]
$$

dan

$$
\begin{aligned}
y= & {\left[I(T) e^{\alpha(T-t)}-h e^{-t \alpha}\right] } \\
& \times\left[\frac{g(t)+g(T)}{2}+\sum_{k=1}^{n-1} g(k h)\right]
\end{aligned}
$$

serta

$\hat{\beta}(t) \approx \frac{w(t)}{x z}, t>T$

dengan

$$
\begin{aligned}
z= & {\left[I(T) e^{\alpha(T-t)}+h e^{-t \alpha}\right] } \\
& \times\left[\frac{g(t)+g(T)}{2}+\sum_{k=1}^{n-1} g(k h)\right]
\end{aligned}
$$

dan

$$
g(m)=e^{\alpha m} w(m)
$$

Serta fungsi indensi $w(t)$ yang merupakan jumlah kasus baru per waktu. Jadi insidensi adalah kuantitas $w=\beta S I$ [5]. Adapun $\alpha$ yang merupakan tingkat kesembuhan dari penyakit dapat ditentukan dengan menggunakan formula dari [1] dimana tingkat kesembuhan atau case recovery rate (CRR) diformulasikan sebagai berikut

$$
\alpha=\frac{R(t)}{R(t)+D(t)}
$$

Dan tingkat kematian atau mortality rate sebagai case fatality rate (CFR) sehingga

$$
\mu=\frac{D(t)}{R(t)+D(t)}
$$


Model Asuransi Kesehatan Penyakit Menular

Pada asuransi kesehatan penyakit menular, pemilik polis asuransi kesehatan membayarkan premi kepada perusahaan asuransi sebagai penanggung dan pemegang polis sendiri akan mendapatkan santunan berupa biaya perawatan saat terinfeksi penyakit sampai sembuh dan santunan kematian jika meninggal karena penyakit infeksi tersebut. Proses ini didasarkan pada model epidemologi SIR seperti yang terlihat pada gambar berikut

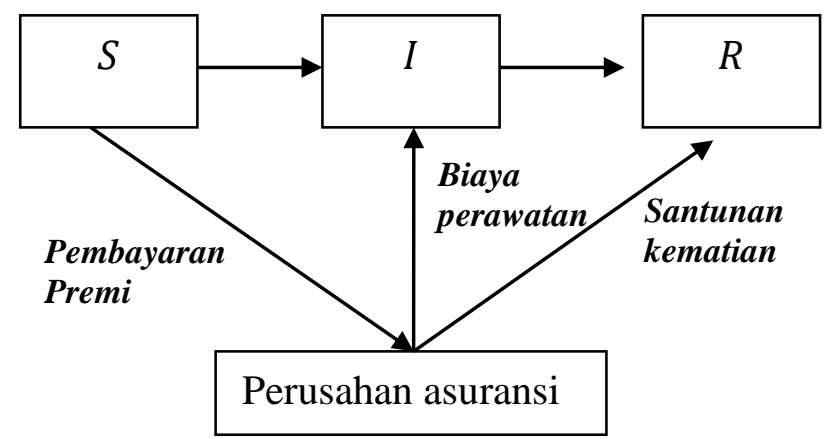

Gambar 2.3 Model asuransi penyakit menular berdasarkan pada model kompartemen SIR

(Sumber: Feng, 2006)

Pada model epidemi deterministik yang dikemukakan oleh Hainaut [7], $S_{0}$ merupakan populasi yang terkena penyakit epidemi di waktu $t=0$. Pada model ini jumlah orang yang terinfeksi di waktu $t \geq 0$ dinotasikan dengan $I_{t}$ berdasarkan pada persamaan berikut

$$
I(t)=S_{0} e^{-(\alpha+\mu) t}(\beta t)^{\gamma}, t \geq t_{0}
$$

dengan $\alpha, \beta, \mu, \gamma \in \mathbb{R}^{+}$. Paremeter $\alpha$ adalah tingkat kesembuhan (recovery rate) dari penyakit, $\mu$ adalah tingkat kematian (mortality rate), $\gamma$ adalah tingkat penularan per kapita yang dimana dalam model SIR sama dengan tingkat penularan yang proporsional terhadap populasi individu yang suspek atau dengan kata lain

$$
\frac{\beta_{S I R} S_{t}^{S I R}}{S_{0}}=\frac{\gamma}{t}
$$

Mekanisme penentuan premi dalam model asuransi ini adalah sebagai berikut:
1. Setiap individu dalam populasi akan membayarkan premi kepada perusahaan asuransi yang menawarkan produk asuransi penyakit infeksi emerging

2. Saat individu terinfeksi penyakit infeksi emerging, maka perusahaan asuransi akan membayarkan santunan untuk biaya perawatan individu tersebut hingga sembuh

3. Apabila invidu yang terinfeksi itu meninggal, maka perusahaan juga akan membayarkan santunan kepada keluarga individu yang bersangkutan

Oleh karena itu, untuk menentukan nilai premi yang harus dibayarkan peserta asuransi infeksi emerging maka digunakan persamaan berikut

$$
p=\frac{(b+c \mu) S_{0} \beta^{\gamma} \theta^{-\gamma-1} \Gamma_{l}(\gamma+1, T \theta)}{\int_{0}^{T} e^{-r s} S_{s} d s}
$$

dengan

$$
\Gamma_{l}(\gamma+1, T \theta)=\int_{0}^{\theta T} u^{\gamma} e^{-u} d u \text { yang }
$$

merupakan gamma lower incomplete function dan $\theta=r+\alpha+\mu$. Adapun $b$ dan $c$ secara berturut-turut adalah besaran santunan untuk perawatan pasien hingag sembuh dan santunan kematian jika pasien meninggal[7]

\section{METODOLOGI PENELITIAN}

\section{Sumber Data}

Data yang digunakan pada penelitian ini adalah data jumlah kasus harian covid di Indonesia tahun 2020 Q2 (Bulan April 2020Juni 2020)

\section{Prosedur Penentuan Nilai Premi}

1. Mengumpulkan data jumlah kasus harian Covid-19

2. Menggambarkan grafik fungsi dari kasus harian penderita Covid-19

3. Estimasi tingkat transmisi atau penularan

4. Estimasi tingkat kesembuhan

5. Estimasi tingkat kematian

6. Menentukan interval waktu

7. Menentukan nilai premi 


\section{HASIL DAN PEMBAHASAN}

Pada grafik berikut digambarkan jumlah individu yang terinfeksi, sembuh dan meninggal di Indonesia pada kuartal ke-2 tahun 2020

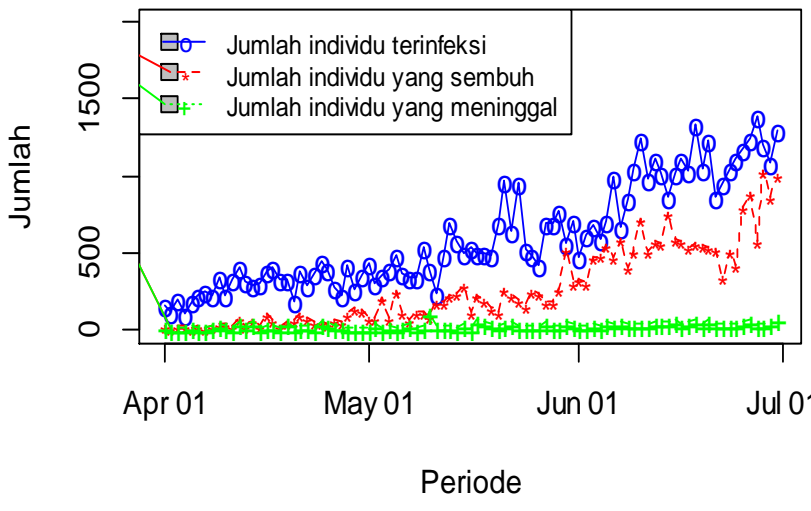

Gambar 2.4 Grafik perkembangan kasus Covid-

19 di kuartal ke-2 tahun 2020

Selanjutnya berdasarkan data tersebut, ditentukan fungsi indensi $w(t)$ yang merupakan jumlah kasus baru setiap harinya. Dengan menggunakan formula CRR dan CFR diperoleh nilai $\alpha$ dan $\mu$ setiap hari selama 90 hari.

Tabel 4.1 Parameter nilai $\alpha$ dan $\mu$

\begin{tabular}{|l|l|l|l|l|l|}
\hline $\mathrm{t}$ & $\alpha$ & $\mu$ & $\mathrm{t}$ & $\alpha$ & $\mu$ \\
\hline 1 & 0,51163 & 0,48837 & 24 & 0,50000 & 0,50000 \\
\hline 2 & 0,59091 & 0,40909 & 25 & 0,56338 & 0,43662 \\
\hline 3 & 0,66667 & 0,33333 & 26 & 0,73864 & 0,26136 \\
\hline 4 & 0,61538 & 0,38462 & 27 & 0,66667 & 0,33333 \\
\hline 5 & 0,45161 & 0,54839 & 28 & 0,92793 & 0,07207 \\
\hline 6 & 0,71795 & 0,28205 & 29 & 0,92568 & 0,07432 \\
\hline 7 & 0,50000 & 0,50000 & 30 & 0,94245 & 0,05755 \\
\hline 8 & 0,51351 & 0,48649 & 31 & 0,89610 & 0,10390 \\
\hline 9 & 0,57143 & 0,42857 & 32 & 0,70476 & 0,29524 \\
\hline 10 & 0,53571 & 0,46429 & 33 & 0,93778 & 0,06222 \\
\hline 11 & 0,84000 & 0,16000 & 34 & 0,80412 & 0,19588 \\
\hline 12 & 0,61345 & 0,38655 & 35 & 0,96813 & 0,03187 \\
\hline 13 & 0,55319 & 0,44681 & 36 & 0,83916 & 0,16084 \\
\hline 14 & 0,56604 & 0,43396 & 37 & 0,64646 & 0,35354 \\
\hline 15 & 0,66667 & 0,33333 & 38 & 0,89683 & 0,10317 \\
\hline 16 & 0,79070 & 0,20930 & 39 & 0,87597 & 0,12403 \\
\hline 17 & 0,71084 & 0,28916 & 40 & 0,44390 & 0,55610 \\
\hline 18 & 0,61538 & 0,38462 & 24 & 0,50000 & 0,50000 \\
\hline 19 & 0,53922 & 0,46078 & 25 & 0,56338 & 0,43662 \\
\hline 20 & 0,88406 & 0,11594 & 26 & 0,73864 & 0,26136 \\
\hline 21 & 0,78512 & 0,21488 & 27 & 0,66667 & 0,33333 \\
\hline 22 & 0,78889 & 0,21111 & 28 & 0,92793 & 0,07207 \\
\hline 23 & 0,79661 & 0,20339 & 29 & 0,92568 & 0,07432 \\
\hline 30 & 0,94245 & 0,05755 & 58 & 0,88835 & 0,11165 \\
\hline & & & & & \\
\hline
\end{tabular}

\begin{tabular}{|l|l|l|l|l|l|}
\hline 31 & 0,89610 & 0,10390 & 59 & 0,91304 & 0,08696 \\
\hline 32 & 0,70476 & 0,29524 & 60 & 0,90799 & 0,09201 \\
\hline 33 & 0,93778 & 0,06222 & 61 & 0,87988 & 0,12012 \\
\hline 34 & 0,80412 & 0,19588 & 62 & 0,92157 & 0,07843 \\
\hline 35 & 0,96813 & 0,03187 & 63 & 0,93125 & 0,06875 \\
\hline 36 & 0,83916 & 0,16084 & 64 & 0,93083 & 0,06917 \\
\hline 37 & 0,64646 & 0,35354 & 65 & 0,95481 & 0,04519 \\
\hline 38 & 0,89683 & 0,10317 & 66 & 0,91833 & 0,08167 \\
\hline 39 & 0,87597 & 0,12403 & 67 & 0,93737 & 0,06263 \\
\hline 40 & 0,44390 & 0,55610 & 68 & 0,92200 & 0,07800 \\
\hline 30 & 0,94245 & 0,05755 & 69 & 0,92694 & 0,07306 \\
\hline 31 & 0,89610 & 0,10390 & 70 & 0,92727 & 0,07273 \\
\hline 32 & 0,70476 & 0,29524 & 71 & 0,95206 & 0,04794 \\
\hline 33 & 0,93778 & 0,06222 & 72 & 0,92518 & 0,07482 \\
\hline 34 & 0,80412 & 0,19588 & 73 & 0,92320 & 0,07680 \\
\hline 35 & 0,96813 & 0,03187 & 74 & 0,92904 & 0,07096 \\
\hline 41 & 0,91045 & 0,08955 & 75 & 0,94612 & 0,05388 \\
\hline 42 & 0,91919 & 0,08081 & 76 & 0,90244 & 0,09756 \\
\hline 43 & 0,91429 & 0,08571 & 77 & 0,94617 & 0,05383 \\
\hline 44 & 0,93902 & 0,06098 & 78 & 0,92308 & 0,07692 \\
\hline 45 & 0,89623 & 0,10377 & 79 & 0,89806 & 0,10194 \\
\hline 46 & 0,89256 & 0,10744 & 80 & 0,94188 & 0,05812 \\
\hline 47 & 0,78700 & 0,21300 & 81 & 0,90508 & 0,09492 \\
\hline 48 & 0,81933 & 0,18067 & 82 & 0,93537 & 0,06463 \\
\hline 49 & 0,82659 & 0,17341 & 83 & 0,90437 & 0,09563 \\
\hline 50 & 0,83721 & 0,16279 & 84 & 0,93531 & 0,06470 \\
\hline 51 & 0,87960 & 0,12040 & 85 & 0,91648 & 0,08352 \\
\hline 52 & 0,82022 & 0,17978 & 86 & 0,94391 & 0,05609 \\
\hline 53 & 0,88479 & 0,11521 & 87 & 0,93347 & 0,06653 \\
\hline 54 & 0,87931 & 0,12069 & 88 & 0,93964 & 0,06036 \\
\hline 55 & 0,92664 & 0,07336 & 89 & 0,96795 & 0,03205 \\
\hline 56 & 0,89695 & 0,10305 & 90 & 0,94426 & 0,05574 \\
\hline 57 & 0,76596 & 0,23404 & 91 & 0,93408 & 0,06592 \\
\hline
\end{tabular}

Selanjutnya diestimasi tingkat transmisi setiap harinya yaitu $\beta(t)$ seperti pada formula sebelumnya sehingga diperoleh nilai $\beta(t)$. Untuk menentukan besaran premi digunakan formula (2.10) dan nilai masing-masing parameter $\beta, \theta, \gamma$ menggunakan nilai rataan dari nilai harian setiap parameter seperti pada tabel berikut

Tabel 4.1 Parameter Perhitungan Premi

\begin{tabular}{|l|l|}
\hline Variabel & Nilai \\
\hline$\mu$ & 0.182362 \\
\hline$S_{0}$ & 270.203 .918 \\
\hline$\beta$ & $1,813267 \times 10^{-11}$ \\
\hline$\gamma$ & $9,634257 \times 10^{-10}$ \\
\hline$\theta$ & 1,044643 \\
\hline
\end{tabular}


sehingga diperoleh nilai premi untuk nilai $b$ dan $c$ yang beragam seperti pada tabel berikut ini

Tabel 4.2 Tabel Tingkat Premi

\begin{tabular}{|c|c|c|}
\hline \multicolumn{1}{l|}{ b } & \multicolumn{1}{l|}{ Tingkat Premi $(\mathbf{P})$} \\
\hline 5 & 10 & 0,021358598 \\
\hline 10 & 20 & 0,042717197 \\
\hline 15 & 30 & 0,064075795 \\
\hline 20 & 40 & 0,085434394 \\
\hline 25 & 50 & 0,106792992 \\
\hline 30 & 60 & 0,128151591 \\
\hline 35 & 70 & 0,149510189 \\
\hline 40 & 80 & 0,170868788 \\
\hline 45 & 90 & 0,192227386 \\
\hline 50 & 100 & 0,213585985 \\
\hline 55 & 110 & 0,234944583 \\
\hline 60 & 120 & 0,256303182 \\
\hline 65 & 130 & 0,27766178 \\
\hline 70 & 140 & 0,299020379 \\
\hline 75 & 150 & 0,320378977 \\
\hline 80 & 160 & 0,341737575 \\
\hline 85 & 170 & 0,363096174 \\
\hline 90 & 180 & 0,384454772 \\
\hline 95 & 190 & 0,405813371 \\
\hline 100 & 200 & 0,427171969 \\
\hline
\end{tabular}

Terlihat pada tabel diatas, jika santunan kematian dan santunan untuk pengobatan rumah sakit semakin tinggi maka tingkat premi pun semakin tinggi. Hal ini disebabkan karena parameter lain yang digunakan dalam premi dianggap konstan. Premi tersebut dapat digambarkan pada grafik berikut

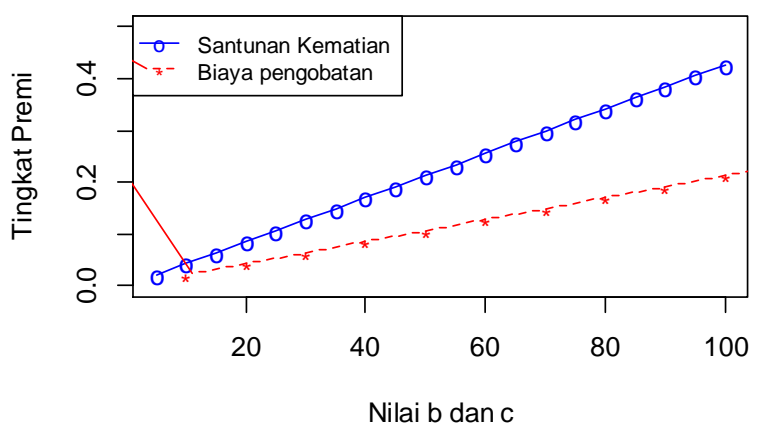

Gambar 2.4 Grafik tingkat premi dengan jumlah santunan kematian serta biaya perawatan yang berbeda nilanya

\section{KESIMPULAN}

Penentuan premi merupakan hal yang sangat penting dalam pemasaran produk asuransi. Pada asuransi penyakit infeksi emerging, premi juga harus ditentukan secara"fair" dengan mempertimbangkan jumlah santunan untuk biaya rumah sakit dan jika terjadi kematian. Hal yang tidak kalah penting adalah mempertimbangkan jumpah populasi, jumlah kasus infeksi, sembuh, dan meninggal pada populasi yang menjadi objek. Hasil penelitian ini menunjukkan dengan menganggap tingkat penularan, kematian, dan kesembuhan konstan, berdasarkan model epidemologi SIR maka diperoleh tingkat premi akan semakin meningkat seriring meningkatnya besaran santunan kematian dan biaya pengobatan pasien.

\section{DAFTAR PUSTAKA}

[1] Abdullatif Khafaie, M., \& Rahim, F. (2021). Estimating Case Fatality and Case Recovery Rates of COVID-19: is this the right thing to do? Central Asian Journal of Global Health. https://doi.org/10.5195/cajgh.2021.489

[2] Djafri, D. (2017). PEMODELAN EPIDEMIOLOGI

MENULAR. Jurnal Kesehatan Masyarakat Andalas. https://doi.org/10.24893/jkma.v10i1.172

[3] Feng, R. (2006). Application of Epidemiological Models in Actuarial Mathematics. Statistics.

[4] Feng, R., \& Garrido, J. (2011). Actuarial Applications of Epidemiological Models. North American Actuarial Journal. https://doi.org/10.1080/10920277.2011.105 97612

[5] Hadeler, K. P. (2011). Parameter identification in epidemic models. Mathematical Biosciences. https://doi.org/10.1016/j.mbs.2010.12.004

[6] Haider, N., Rothman-Ostrow, P., Osman, 
A. Y., Arruda, L. B., Macfarlane-Berry, L., Elton, L., ... Kock, R. A. (2020). COVID19-Zoonosis or Emerging Infectious Disease? Frontiers in Public Health. https://doi.org/10.3389/fpubh.2020.596944

[7] Hainaut, D. (2021). An actuarial approach for modeling pandemic risk. Risks. https://doi.org/10.3390/risks9010003

[8] Lefèvre, C., Picard, P., \& Simon, M. (2017). Epidemic risk and insurance coverage. Journal of Applied Probability. https://doi.org/10.1017/jpr.2016.100

[9] Li, M. Y. (2018). An Introduction to Mathematical Modeling of Infectious Diseases. In An Introduction to Mathematical Modeling of Infectious Diseases. https://doi.org/10.1007/978-3319-72122-4

[10] Mubayi, A., Pandey, A., Brasic, C., Mubayi, A., Ghosh, P., \& Ghosh, A. (2021). Analytical estimation of datamotivated time-dependent disease transmission rate: An application to ebola and selected public health problems. Tropical Medicine and Infectious Disease. https://doi.org/10.3390/tropicalmed603014 1

[11] Mengenal Penyakit Infeksi Emerging. https://infeksiemerging.kemkes.go.id/men genal-penyakit-infeksi-emerging. Diakses tanggal 12 Juni 2021

[12] World Health Organization. Regional Office for South-East Asia. (2005). Combating emerging infectious diseases in the South-East Asia Region. WHO Regional Office for South-East Asia. https://apps.who.int/iris/handle/10665/204 878

[13] World Health Organization. Regional Office for South-East Asia. (2014). A brief guide to emerging infectious diseases and zoonoses. WHO Regional Office for South-East Asia. https://apps.who.int/iris/handle/10665/204 722

[14] Peraturan Menteri Kesehatan Republik Indonesia Nomor 59 Tahun 2016 Tentang Pembebasan Biaya Pasien Penyakit Infeksi Emerging Tertentu. http://www.bphn.go.id/data/documents/16 pmkes059.pdf. Diakses pada tanggal 20 Juni 2021

[15] Ulya, F.N., (2021). "Akibat Covid-19, Kerugian Ekonomi Tahun 2020 Capai Rp 1.356

Triliun". https://money.kompas.com/read/2021/04/ 29/143647026/akibat-covid-19-kerugianekonomi-tahun-2020-capai-rp-1356triliun?page $=$ all. Diakses pada tanggal 05 Agustus 2021.

[16] Vynnycky, E. and White, R. (2010). An Introduction to Infectious Disease Modelling. Oxford University Press, Oxford. 